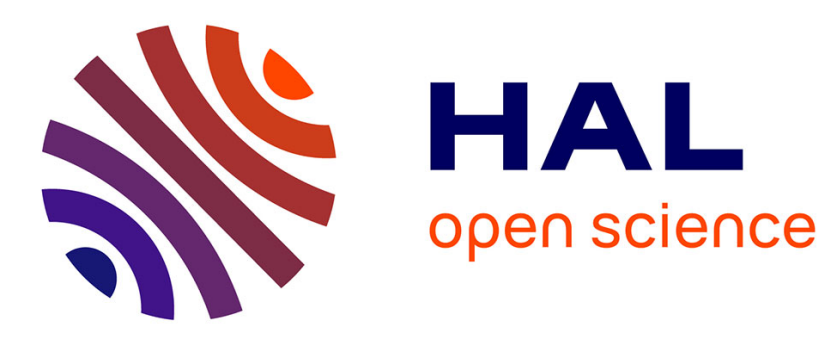

\title{
Effects of dietary protein level and amino acid supplementation on performance of mixed-parity lactating sows in a tropical humid climate
} B.A.N. Silva, Jean Noblet, J.L. Donzele, R.F.M. Oliveira, Yvan Primot, Jean-Luc Gourdine, David Renaudeau

\section{To cite this version:}

B.A.N. Silva, Jean Noblet, J.L. Donzele, R.F.M. Oliveira, Yvan Primot, et al.. Effects of dietary protein level and amino acid supplementation on performance of mixed-parity lactating sows in a tropical humid climate. Journal of Animal Science, 2009, 87 (12), pp.4003-4012. 10.2527/jas.20081176. hal-02663004

\section{HAL Id: hal-02663004 https: / hal.inrae.fr/hal-02663004}

Submitted on 31 May 2020

HAL is a multi-disciplinary open access archive for the deposit and dissemination of scientific research documents, whether they are published or not. The documents may come from teaching and research institutions in France or abroad, or from public or private research centers.
L'archive ouverte pluridisciplinaire HAL, est destinée au dépôt et à la diffusion de documents scientifiques de niveau recherche, publiés ou non, émanant des établissements d'enseignement et de recherche français ou étrangers, des laboratoires publics ou privés. 


\section{JOURNAL OF ANIMAL SCIENCE}

The Premier Journal and Leading Source of New Knowledge and Perspective in Animal Science

\section{Effects of dietary protein level and amino acid supplementation on performance of mixed-parity lactating sows in a tropical humid climate}

B. A. N. Silva, J. Noblet, J. L. Donzele, R. F. M. Oliveira, Y. Primot, J. L. Gourdine and D. Renaudeau

\section{J ANIM SCI 2009, 87:4003-4012.}

doi: 10.2527/jas.2008-1176 originally published online September 11, 2009

The online version of this article, along with updated information and services, is located on the World Wide Web at:

http://www.journalofanimalscience.org/content/87/12/4003 


\title{
Effects of dietary protein level and amino acid supplementation on performance of mixed-parity lactating sows in a tropical humid climate ${ }^{1}$
}

\author{
B. A. N. Silva, ${ }^{*} \dagger$ J. Noblet,$\ddagger$ J. L. Donzele,$\dagger$ R. F. M. Oliveira, $\uparrow$ Y. Primot,$\S$ \\ J. L. Gourdine, ${ }^{*}$ and D. Renaudeau*2
}

*INRA, Unité de Recherches Zootechniques INRA UR143, 97170 Petit Bourg, Guadeloupe, French West Indies; $\dagger$ Animal Science Department/Departamento de Zootecnia, Universidade Federal de Viçosa (UFV), 36571-000 Viçosa, MG, Brazil; †INRA, UMR Systèmes d'Elevage, Nutrition Animale et Humaine

INRA UMR 1079, 35590 St-Gilles, France; and §Ajinomoto Eurolysine SAS 153, rue de Courcelles, 75817 Paris Cedex 17, France

\begin{abstract}
Eighty-six mixed-parity Large White sows were used to determine the effect of diets with reduced $\mathrm{CP}$ content or supplemented with essential AA on 28-d lactation performance under humid tropical climatic conditions. This experiment was conducted in Guadeloupe (West French Indies, latitude $16^{\circ} \mathrm{N}$, longitude $61^{\circ} \mathrm{W}$ ) between February 2007 and January 2008. Two seasons were distinguished a posteriori from climatic measurement variables continuously recorded in the farrowing room. The average minimum and maximum ambient temperatures and average daily relative humidity for the warm season were 20.5 and $28.2^{\circ} \mathrm{C}$, and $93.8 \%$, respectively. The corresponding values for the hot season were 22.7 and $29.4^{\circ} \mathrm{C}$, and $93.7 \%$, respectively. The dietary experimental treatments were a normal protein $\operatorname{diet}(\mathrm{NP})$, a low protein $\operatorname{diet}(\mathrm{LP})$, and a NP diet $(\mathrm{NP}+)$ supplemented with essential AA. The NP and LP diets supplied the same levels of standardized digestible Lys (i.e., $0.80 \mathrm{~g} / \mathrm{MJ}$ of $\mathrm{NE}$ ), and the $\mathrm{NP}+$ diet supplied $0.95 \mathrm{~g} / \mathrm{MJ}$ of NE. No interaction between season and diet composition was noted on any response variable evaluated. The ADFI was decreased
\end{abstract}

$(P<0.05)$ in the hot season (i.e., 3.69 vs. $4.72 \mathrm{~kg})$ and therefore decreased by $500 \mathrm{~g}$ per ${ }^{\circ} \mathrm{C}$ increase of ambient temperature under high relative humidity conditions. The ADFI tended to be greater with the LP and $\mathrm{NP}+$ diets when compared with the NP treatment (i.e., $+10 \%, P=0.08)$. Litter $\mathrm{BW}$ gain and mean $\mathrm{BW}$ of piglets at weaning were greater $(P<0.05)$ during the warm season than during the hot season ( 2.3 vs. 1.8 $\mathrm{kg} / \mathrm{d}$ and 7.5 vs. $7.1 \mathrm{~kg}$, respectively). Milk production and composition were not affected by dietary treatments but were affected by season ( 8.1 vs. $6.8 \mathrm{~kg} / \mathrm{d}$, for warm and hot seasons, respectively; $P<0.01)$. The sows fed $\mathrm{LP}$ and $\mathrm{NP}+$ diets tended to have decreased backfat thickness losses $(3.3$ and $3.8 \mathrm{~mm}$, respectively; $P>0.08)$. In conclusion, the hot season in humid tropical climates, which combines high levels of temperature and humidity, has a pronounced negative impact on performance of lactating sows. Diets with low CP content or supplemented with essential AA can attenuate the effects of hot and humid season by increasing ADFI in lactating sows.

Key words: feed intake, lactation, lysine, protein, sow, tropical climate

(0)2009 American Society of Animal Science. All rights reserved.

J. Anim. Sci. 2009. 87:4003-4012

doi:10.2527/jas.2008-1176

\section{INTRODUCTION}

\footnotetext{
${ }^{1}$ The authors gratefully acknowledge Ajinomoto Eurolysine (Paris, France) for their financial support and for measurement of AA content in feeds; and CAPES (Coordenação de Aperfeiçoamento de Pessoal de Nivel Superior, Brasilia, Brazil) for the grant to B. A. N. Silva during his $\mathrm{PhD}$ research at INRA. The authors also gratefully acknowledge C. Anäis, M. Bructer, K. Benoni, T. Etienne, and G. Saminadin for their technical assistance.

${ }^{2}$ Corresponding author: David.Renaudeau@antilles.inra.fr Received May 13, 2008.

Accepted August 6, 2009.
}

According to Food and Agriculture Organization predictions, pig production in tropical and subtropical countries will rapidly increase as a result of increasing human population. Although many factors are obviously involved, the combination of high temperatures and high relative humidity $(\mathbf{R H})$ resulting in heat stress remains one of the major problems that affects the production efficiency of pigs in these regions. According to their high nutrient requirements, lactating sows are particularly sensitive to high ambient temperatures. 
When ambient temperature increases above the evaporative critical temperature (i.e., $22^{\circ} \mathrm{C}$; Quiniou and Noblet, 1999), the sow reduces voluntary feed intake to reduce heat production due to the thermal effect of feed (TEF). This reduced voluntary feed intake has negative consequences on body reserves mobilization, milk production, and future reproductive and productive career of the sow (Dourmad et al., 1998). Alternatives to reduce heat stress have been developed to maintain sows performance under high temperature conditions by increasing heat loss using a neck drip cooling system (McGlone et al., 1988), chilled drinking water (Jeon et al., 2006), or a floor cooling system (Silva et al., 2006). An alternative approach consists of attenuating the change of feed intake in hot conditions. The TEF of digestible fat, starch, and protein averages 10, 18, and $42 \%$ of the ME content (Noblet et al., 1994). Therefore, diets with reduced protein content decrease heat production and may attenuate the effect of elevated temperature on feed consumption. These nutritional solutions were successfully tested in temperate conditions (Renaudeau et al., 2001; Le Bellego et al., 2002). In contrast, very little has been published on the effects of diet manipulation on performance of sows raised in a tropical, humid climate.

The first objective of our study was to evaluate the effect of diets with low TEF on feed consumption and performance of lactating sows under tropical, humid conditions. The second objective of the experiment was to determine if adding AA to basal diet can attenuate the effect of heat stress on maternal body reserve mobilization in heat-stressed lactating sows.

\section{MATERIALS AND METHODS}

Care and use of animals were performed according to the certificate of authorization to experiment on living animals issued by the French Ministry of Agriculture.

\section{Experimental Design}

Ten successive replicates of 8 to 10 mixed-parity Large White sows $(\mathrm{n}=89$ in total) were used in an experiment conducted at the INRA experimental facilities in Guadeloupe, French West Indies (latitude $16^{\circ} \mathrm{N}$, longitude $61^{\circ} \mathrm{W}$ ) considered a tropical humid climate area (Berbigier, 1988). This study covered the period between February 2007 and January 2008. Two seasons were distinguished a posteriori from climatic measurement variables continuously recorded in the farrowing room.

Within each replicate, sows were distributed in a completely randomized experimental design among 3 dietary treatments according to backfat thickness, parity order, and BW after farrowing. The dietary experimental treatments were a normal protein $\operatorname{diet}(\mathbf{N P})$, a low protein diet $(\mathbf{L P})$, and a NP diet supplemented with an AA complement (NP+). The experimental diets (Table 1) were formulated using corn, wheat middlings, and soybean meal, which met or exceeded AA
Table 1. Composition of the lactation diets, as-fed basis $^{1}$

\begin{tabular}{lccc}
\hline \hline Item & $\mathrm{NP}$ & $\mathrm{LP}$ & $\mathrm{NP}+{ }^{2}$ \\
\hline Ingredient, \% & & & \\
Corn & 59.5 & 67.4 & 59.5 \\
Soybean meal & 24.4 & 10.6 & 24.4 \\
Wheat middlings & 8.4 & 14.3 & 8.4 \\
Soybean oil & 3.4 & 2.4 & 3.4 \\
L-Lysine·HCl & 0.020 & 0.415 & 0.020 \\
DL-Methionine & & 0.109 & \\
L-Threonine & & 0.175 & \\
L-Tryptophan & & 0.064 & \\
L-Isoleucine & & 0.127 & \\
L-Valine & & 0.140 & \\
Monocalcium phosphate & 1.0 & 1.0 & 1.0 \\
Calcium carbonate & 2.1 & 2.1 & 2.1 \\
Salt & 0.1 & 0.1 & 0.1 \\
Minerals and vitamins ${ }^{3}$ & 1.1 & 1.1 & 1.1 \\
AA complement, g & & & 53 \\
\hline
\end{tabular}

${ }^{1} \mathrm{NP}=$ normal protein diet; $\mathrm{LP}=$ low protein diet; $\mathrm{NP}+=\mathrm{NP}$ diet supplemented with an AA complement.

${ }^{2}$ The AA complement calculation: lysine content was increased in the NP diet until the other essential AA (Phe + Tyr, His, Arg, Leu) become limiting following the NRC recommendations for AA/Lys: 111, 39, 55, 110, for Phe + Tyr, His, Arg, Leu, respectively. For the calculations of the AA complement, an estimated ADFI of $5,000 \mathrm{~g} / \mathrm{d}$ was used. Fifty-three grams of the AA complement was offered daily to each NP+ sow.

${ }^{3}$ Mineral and vitamin mixture supplied ( $\mathrm{g} / \mathrm{kg}$ of diet): 10 of $\mathrm{Cu}$ (as $\mathrm{CuSO}_{4}$ ); 80 of $\mathrm{Fe}\left(\right.$ as $\mathrm{FeSO}_{4} \cdot 7 \mathrm{H}_{2} \mathrm{O}$ ); 40 of $\mathrm{Mn}$ (as $\mathrm{MnO}$ ); 100 of $\mathrm{Zn}$ (as $\mathrm{ZnO}) ; 0.6$ of I (as $\left.\mathrm{Ca}\left(\mathrm{IO}_{3}\right)_{2}\right) ; 0.10$ of $\mathrm{CO}\left(\right.$ as $\left.\mathrm{CoSO}_{4} \cdot 7 \mathrm{H}_{2} \mathrm{O}\right) ; 0.15$ of $\mathrm{Se}$ (as $\mathrm{Na}_{2} \mathrm{SeO}_{3}$ ); $5,000 \mathrm{IU}$ of vitamin $\mathrm{A} ; 1,000 \mathrm{IU}$ of vitamin $\mathrm{D}_{3} ; 15 \mathrm{IU}$ of vitamin $\mathrm{E} ; 2 \mathrm{mg}$ of vitamin $\mathrm{K}_{3} ; 2 \mathrm{mg}$ of thiamine; $4 \mathrm{mg}$ of riboflavin; 20 $\mathrm{mg}$ of nicotinic acid; $10 \mathrm{mg}$ of D-pantothenic acid; $3 \mathrm{mg}$ of pyroxidine; $0.02 \mathrm{mg}$ of vitamin $\mathrm{B}_{12} ; 1.0 \mathrm{mg}$ of folic acid; and $0.2 \mathrm{mg}$ of biotin.

requirements of lactating sows (NRC, 1998). The NP and LP diets contained the same levels of standardized digestible Lys (i.e., $0.80 \mathrm{~g} / \mathrm{MJ}$ of $\mathrm{NE}$ ), and the $\mathrm{NP}+$ diet contained $0.95 \mathrm{~g} / \mathrm{MJ}$ of NE. For the calculation of the AA complement composition in the NP+ treatment, an ADFI of $5 \mathrm{~kg}$ was assumed, and the Lys level was increased until the first essential AA became limiting (i.e., Phe + Tyr), after available synthetic AA (L-Lys, DL-Met, L-Thr, L-Trp, L-Val, L-Ile) were added to maintain a constant ratio between the essential AA and Lys. Each morning, $53 \mathrm{~g}$ of the calculated AA complement was incorporated manually into the NP diet before distribution to the sows. The levels of digestible essential AA relative to digestible Lys were similar for the 3 diets. The ratio between digestible essential $\mathrm{AA}$ and digestible Lys in the experimental diets was calculated to ensure that they were not below that of the ideal protein recommended for this animal category (Renaudeau et al., 2003). Chemical composition and nutritional value of diets are presented in Table 2. Diets were offered as pellets. Feeds were prepared for 1 or 2 successive replicates and stored in a temperaturecontrolled room $\left(24^{\circ} \mathrm{C}, 50\right.$ to $\left.60 \% \mathrm{RH}\right)$.

\section{Animal Management}

During the gestation period, sows were housed in open-fronted gestating pens in groups of 5 sows each 
and restrictively fed a conventional diet containing 13 MJ of DE $/ \mathrm{kg}, 140 \mathrm{~g}$ of $\mathrm{CP} / \mathrm{kg}$, based on maize, wheat middling, and soybean meal. Feed allowance during the first $30 \mathrm{~d}$ after mating was calculated to standardize body condition at farrowing, according to the model proposed by Dourmad et al. (1997). The feeding level was fixed at $2.5 \mathrm{~kg} / \mathrm{d}$ from d 30 to 114 of gestation. Ten days before parturition, sows were moved to openfronted farrowing pens $(2.1 \times 2.2 \mathrm{~m})$ on a slatted metal floor. Variations in ambient temperature, $\mathrm{RH}$, and photoperiod closely followed outdoor conditions. On d 1 postpartum, sows received $1 \mathrm{~kg}$ of the standard gestation diet and the allowance increased by $1 \mathrm{~kg}$ each day until d 4 of lactation to avoid overconsumption at the beginning of lactation and agalactia problems. The proportion of gestation diet decreased progressively over the 4 -d postpartum $(100,75,50$, and 25 on $\mathrm{d} 1,2,3$, and 4 , respectively), and sows were fed only the lactation diet on d 5 . From d 6 to 26 postpartum, sows were allowed to consume feed ad libitum. The day before weaning (i.e., d 27), sows were allowed only $3 \mathrm{~kg}$ of feed (i.e., at least $1.5 \mathrm{~kg}$ less than their usual feed intake) to standardize consumption for all sows for determination of sow BW at weaning.

After birth, piglets were handled for tooth cutting, umbilical cord treatment, and ear tagged for labeling. On d 3, they received an intramuscular injection of 200 $\mathrm{mg}$ of iron dextran. As necessary, cross-fostering was conducted within the first $48 \mathrm{~h}$ after birth to standardize litter size at 11 piglets. On d 14, male piglets were castrated. After $21 \mathrm{~d}$ of lactation, piglets were offered creep feed containing $15.3 \mathrm{MJ}$ of $\mathrm{DE} / \mathrm{kg}, 20 \% \mathrm{CP}$, and $1.47 \%$ total Lys. Infrared lights provided supplemental heat for the piglets during the first $21 \mathrm{~d}$ of the lactation period. At weaning, sows were moved to a breeding facility and were presented to a mature boar twice daily to detect onset of standing estrus. From $28 \mathrm{~d}$ after mating, all sows were checked for pregnancy diagnosis using ultrasonography (Agroscan, ECM, Angoulême, France).

\section{Measurements and Chemical Analyses}

Sows were weighed after farrowing and at weaning. Backfat thickness measurements were taken ultrasonically (Agroscan, ECM) at $65 \mathrm{~mm}$ from the midline at the point beside the shoulder and at the last rib on each flank $2 \mathrm{~d}$ before farrowing and at weaning. The total number of piglets born, born alive, stillborn, and piglet deaths during lactation were recorded for each litter. Piglets were individually weighed at birth, at d 14 and 21 of lactation, and at weaning. Every morning, feed refusals were collected, and fresh feed was immediately distributed once per day between 0700 and 0900 h. Feed consumption was determined as the difference between feed allowance and the refusals collected on the next morning. Every day, 1 sample of feed and feed refusals were collected daily for DM content measurement, and successive samples were pooled and stored at $4^{\circ} \mathrm{C}$
Table 2. Analyzed chemical composition of the lactation $\operatorname{diets}^{1}$

\begin{tabular}{lrrr}
\hline \hline Analyzed composition & NP & LP & NP + \\
\hline Ash & 5.5 & 5.3 & 5.6 \\
CP & 17.3 & 14.1 & 17.6 \\
Starch & 39.0 & 45.2 & 39.0 \\
Ether extract & 4.3 & 5.6 & 4.3 \\
NDF & 10.0 & 10.8 & 10.0 \\
ADF & 2.5 & 2.7 & 2.5 \\
Standardized digestible AA & & & \\
Lys & 0.80 & 0.80 & 0.97 \\
Met + Cys & 0.49 & 0.48 & 0.68 \\
Thr & 0.54 & 0.54 & 0.66 \\
Trp & 0.18 & 0.17 & 0.21 \\
Ile & 0.63 & 0.54 & 0.77 \\
Leu & 1.36 & 1.07 & 1.36 \\
Val & 0.71 & 0.65 & 0.86 \\
Phe & 0.82 & 0.56 & 0.82 \\
Tyr & 0.59 & 0.41 & 0.59 \\
Trp:LNAA, ${ }^{2} \%$ & 4.52 & 5.37 & 4.83 \\
Calculated nutritional value & 37 \\
NE, MJ/kg & & & \\
Digestible Lys, g/MJ of NE & 10.2 & 10.1 & 10.2 \\
NE/ME, \% & 0.80 & 0.80 & 0.95 \\
\hline I & 71.6 & 73.5 & 71.6 \\
\hline
\end{tabular}

${ }^{1}$ Measured or calculated values adjusted for $88 \%$ DM. NP $=$ normal protein diet; $\mathrm{LP}=$ low protein diet; $\mathrm{NP}+=\mathrm{NP}$ diet supplemented with an AA complement.

${ }^{2}[$ Percentage of Trp $/(\%$ Ile $+\%$ Leu $+\%$ Val $+\%$ Phe $+\%$ Tyr $)]$ $\times 100$. LNAA $=$ long neutral AA.

${ }^{3}$ Net energy values were estimated from the chemical composition of the diet using the equation of Noblet et al. (1994). Standardized digestible AA contents were calculated from the analyzed AA content and estimated standardized digestibility coefficients from INRA Tables (Sauvant et al., 2002).

for further analyses. Before sampling the NP+ refusal, these were homogenized manually to guarantee that during the sampling, residues of the AA complement were also incorporated to the sample. Rectal temperatures and respiratory rate of each sow were measured on Monday and Thursday at 0700 and $1200 \mathrm{~h}$ from Monday before farrowing to the Monday after weaning. Ambient temperature and $\mathrm{RH}$ were continuously recorded (1 measurement every $30 \mathrm{~s}$ ) in the farrowing room, using a probe (Campbell Scientific Ltd., Shepshed, UK) placed $1 \mathrm{~m}$ above the floor.

At d 14, piglets were separated from the sows after suckling, and 50 min later (i.e., equivalent to average suckling interval; Renaudeau and Noblet, 2001), the sow was injected with 10 IU of oxytocin (Intervet, Angers, France) in an ear vein, and all functional mammary glands were hand milked. Samples (approximately $100 \mathrm{~mL}$ ) were immediately stored at $-20^{\circ} \mathrm{C}$ for further analyses.

Feed (2 samples per diet and per replicate) and milk (3 samples per sow) samples were analyzed for DM, ash, fat content (AOAC, 1990), and $\mathrm{CP}(\mathrm{N} \times 6.25$ for feed and $\mathrm{N} \times 6.38$ for milk) according to the Dumas method (AOAC, 1990). Feed was analyzed for crude fiber and for cell wall components (NDF, ADF, and ADL) according to Van Soest and Wine (1967). Lactose content of milk was determined using an enzymatic method (Boehringer Mannheim, reference No. 176303). 
Table 3. Main characteristics of climatic variables ${ }^{1}$

\begin{tabular}{|c|c|c|}
\hline \multirow[b]{2}{*}{ Item } & \multicolumn{2}{|c|}{ Season } \\
\hline & Warm & Hot \\
\hline \multicolumn{3}{|c|}{ Temperature, ${ }^{\circ} \mathrm{C}$} \\
\hline Minimal & 20.7 & 23.3 \\
\hline Maximal & 28.0 & 29.4 \\
\hline Mean & 23.7 & 26.1 \\
\hline \multicolumn{3}{|c|}{ Relative humidity, $\%$} \\
\hline Minimal & 82.3 & 87.0 \\
\hline Maximal & 98.4 & 97.7 \\
\hline Mean & 93.5 & 93.7 \\
\hline
\end{tabular}

${ }^{1}$ Seasons correspond to the means of daily values of ambient temperature and relative humidity. Warm season: February to April 2007 and November 2007 to January 2008. Hot season: May to October 2007.

Feed and milk AA contents were analyzed by Ajinomoto Eurolysine (Amiens, France) using ion-exchange chromatography, except for Trp, which was analyzed using HPLC and fluorimetric detection (Waters 600E, St. Quentin en Yvelines, France).

\section{Calculations and Statistical Analyses}

Daily maximum, minimum, mean, and variance of daily ambient temperature and $\mathrm{RH}$ were averaged for each replicate. These data were used to split the total experiment period between 2 seasons through a principal component analysis (PRINCOMP procedure, SAS Inst. Inc., Cary, NC). The effects of season, diet composition, replicate, parity number, and their interactions on performance of sows and litters were tested the GLM procedure of SAS. The effect of group of sows was tested within the effect of season. The average daily rectal temperature and respiratory rate (defined as the mean of values measurements at 0700 and $1200 \mathrm{~h}$ ) measurements were pooled per sow over the lactation period. These data were analyzed using the same previous model. The effect of lactation stage on daily feed intake was tested with a mixed linear model (MIXED procedure of SAS) for repeated measurements with diet composition, season, and replicate as main effects. The least squares means procedure (PDIFF option of SAS) was used to compare means when a significant $F$-value was obtained. The number of sows returning into estrus before and after $5 \mathrm{~d}$ postweaning were compared using a $\chi^{2}$ test (FREQ procedure of SAS).

\section{RESULTS}

\section{Climatic Measurements}

The warm season was determined to be between February and April 2007 and between November 2007 and January 2008, whereas the hot season corresponded to May to October 2007 period. The average minimum and maximum ambient temperatures and average $\mathrm{RH}$ for the warm season were 20.5 and $28.2^{\circ} \mathrm{C}$, and $93.8 \%$, respectively. The corresponding values for the hot season were 22.7 and $29.4^{\circ} \mathrm{C}$, and $93.7 \%$, respectively. The mean temperature values for warm and hot season were 23.7 and 26.1 , respectively (Table 3 ).

\section{Sow and Litter Performance}

Three sows were removed from the study due to low litter size $(<6$ piglets $)$. No interaction $(P>0.10)$ between season and diet composition was found for all criteria studied. According to the experimental design, parity number averaged 3.2 and was not affected by season or by diet composition. Lactation length was greater in the hot season than in the warm season (29.2 vs. $28.1 \mathrm{~d}$; Table 4 ), but no difference in lactation length was observed between dietary treatments (28.6 d on average).

As presented in Table 4, ADFI was affected $(P<$ 0.001 ) by parity and season with reduced feed consumption in the hot season during the entire lactation period and during the ad libitum period (4.72 vs. 3.69 $\mathrm{kg}$; and 5.36 vs. $4.13 \mathrm{~kg}$, respectively). After farrowing, sows were restrictively fed for $5 \mathrm{~d}$ according to the same feeding plan, and the increase of ADFI was similar for both seasons until d 4 (Figure 1). After d 4, ADFI tended to be greater for LP and NP+ diets as compared with the NP diet during the entire lactation period and during the ad libitum period (i.e., 4.35 vs. 3.89 and 4.91 vs. $4.39 \mathrm{~kg}$, respectively; $P=0.08$ ). The ADFI of sows fed LP and NP+ diets increased with the advancement of lactation after d 4 similarly to NP sows $(P<0.05$; Figure 2). Lactation BW and backfat losses were not affected $(P>0.10)$ by season (Table 4$)$. Lactation BW loss was numerically less for the NP+ than the NP or LP sows $(21.8$ vs. $26.2 \mathrm{~kg} ; P>0.10)$. The $\mathrm{LP}$ and NP+ sows showed numerically less backfat loss than NP sows ( 3.5 vs. $5.4 \mathrm{~mm} ; P=0.10)$. Body protein, lipid, and energy losses were not affected by the treatments $(P>0.10)$. Rectal temperature was greater $(P<0.001)$ in the hot season than in the warm season $\left(38.8\right.$ vs. $\left.38.4^{\circ} \mathrm{C}\right)$.

Litter size and the average piglet BW at birth were not affected $(P>0.10)$ by season. Litter BW gain between birth and weaning and mean BW of piglets at weaning were greater $(P<0.05)$ during the warm season than during the hot season $(2.3$ vs. $1.8 \mathrm{~kg} / \mathrm{d}$ and 7.5 vs. $7.1 \mathrm{~kg})$. Litter BW gain during the lactation period was not affected by dietary treatment $(P>0.10)$. Daily consumption of solid creep feed (Table 5 ) during wk 4 of lactation was not affected by diet composition or by season $(P>0.10)$.

Milk production between $\mathrm{d} 1$ and 21 was greater $(P$ $<0.01)$ in the warm season than in the hot season $(8.1$ vs. $6.8 \mathrm{~kg} / \mathrm{d}$, respectively; Table 5). Milk lipid content was greater in the hot season than in the warm season (38.7 vs. $33.1 \% ; P<0.05$ ), and protein content tended to be less in the warm season ( 27.1 vs. $25.1 \% ; P=0.05$; Table 6). Milk production and composition were not affected by diet.

Reproductive performance was measured for a total of 86 sows, but 5 sows $(3,1$, and 1 sows fed NP, LP, and 
Table 4. Effects of season and diet composition on performance of lactating sows over a 28-d lactation (least squares means)

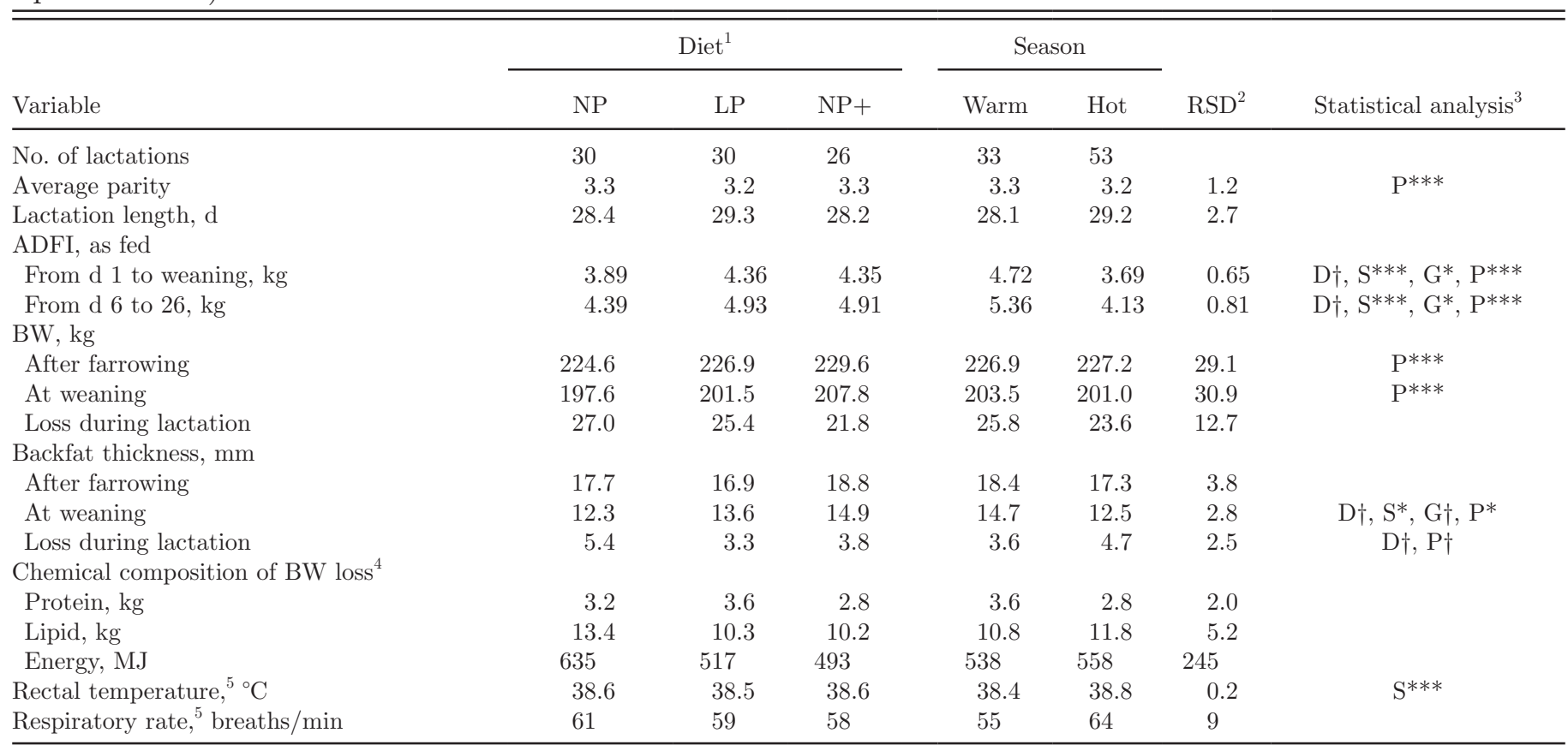

${ }^{1} \mathrm{NP}=$ normal protein diet; $\mathrm{LP}=$ low protein diet; $\mathrm{NP}+=\mathrm{NP}$ diet supplemented with an AA complement.

${ }^{2} \mathrm{RSD}=$ residual SD.

${ }^{3}$ From a GLM analysis including the effects of season (S), diet composition (D), the effect of parity (P), and the effect of batch of sows (G), and their interactions as fixed effects. The interaction between diet and season was not significant $(P>0.10)$.

${ }^{4}$ Estimated from equations published by Dourmad et al. $(1997)$. Protein $(\mathrm{kg})=2.28(2.22)+0.178(0.017) \times \mathrm{empty}$ BW $-0.333(0.067) \times \mathrm{P} 2$ $(\mathrm{RSD}=1.9) ;$ lipids $(\mathrm{kg})=-26.4(4.5)+0.221(0.030) \times$ empty BW $+1.331(0.140) \times \mathrm{P} 2(\mathrm{RSD}=6.1) ;$ energy $(\mathrm{MJ})=-1.075(159)+13.67$ $(1.12) \times$ empty BW $+45.98(4.93) \times \mathrm{P} 2(\mathrm{RSD}=208)$. Empty BW $(\mathrm{kg})=\mathrm{a} \times \mathrm{BW}^{1.013}(\mathrm{~kg})$, with a $=0.912$ at farrowing and a $=0.905$ at weaning. $\mathrm{P} 2=\mathrm{P} 2$ backfat thickness $(\mathrm{mm})$.

${ }^{5}$ Measured at 0700 and $1200 \mathrm{~h}$ every Monday and Thursday during lactation.

${ }^{* * *} P<0.001,{ }^{*} P<0.05, \dagger P<0.10$.

$\mathrm{NP}+$, respectively) did not show estrus until $15 \mathrm{~d}$ after weaning and the weaning-to-estrus interval (WEI) was calculated on a total of 81 sows. The WEI averaged 3.7 and $4.5 \mathrm{~d}(P<0.05)$ for the warm and hot seasons, respectively (Table 7 ). The percentage of sows with a delayed estrus was greater in the hot than in the warm season $(6.2$ vs. $0 \% ; P<0.05)$.

\section{DISCUSSION}

\section{Effect of Season on Sow and Litter Performance}

The effect of high ambient temperatures on the performance of lactating sows and their litters is well established (Black et al., 1993; Renaudeau et al., 2003). In tropical, humid conditions, the average temperatures observed during the warm and the hot seasons are above the upper limit of the thermoneutral zone of the sows (i.e., $22^{\circ} \mathrm{C}$; Quiniou and Noblet, 1999). Under our tropical humid conditions, the mean temperatures observed during the warm and hot season (23.7 and $26.1^{\circ} \mathrm{C}$, respectively) exceeded $22^{\circ} \mathrm{C}$. In addition, the $22^{\circ} \mathrm{C}$ value was determined at low $\mathrm{RH}$, and it probably overestimates the upper limit of the zone of thermoneutrality when the RH is close to $100 \%$. Therefore, lactat- ing sows suffered from heat stress most of the time in our experimental conditions. This effect was accentuated during the hot season due to the greater average daily temperature (i.e., $+2.5^{\circ} \mathrm{C}$ ). This observation is consistent with the increase of rectal temperature (i.e., $+0.4^{\circ} \mathrm{C}$ ), increase of the respiratory rate (i.e., +9 breaths/min), and the sharp reduction of ADFI during the hot season. However, the average rectal temperature recorded during the warm and the hot seasons in this study was less than values measured by Lorschy et al. (1991) and Quiniou and Noblet (1999) at 38.2 vs. $39.3^{\circ} \mathrm{C}$ and 38.6 vs. $39.5^{\circ} \mathrm{C}$, respectively. Moreover, the increase in respiratory rate observed from warm to hot season $\left(+4.0\right.$ breaths $\left.\cdot \min ^{-1} \cdot{ }^{\circ} \mathrm{C}^{-1}\right)$ is less than values reported in other studies using high temperatures $\left(+7.1,+8.9\right.$, and +8.0 breaths $\cdot \min ^{-1} \cdot{ }^{\circ} \mathrm{C}^{-1}$, according to Lorschy et al., 1991; Quiniou and Noblet, 1999; Renaudeau and Noblet, 2001, respectively). The smaller increase observed in the respiratory rate between seasons in our study may be related to the fact that sows in the warm season were already heat stressed, leading to a relatively smaller increase in respiratory rate when exposed to hot season temperature. Taking into account the low cutaneous evaporative capacities in pigs, a significant rise in respiratory rate is required to cause an effective increase of evaporative heat losses. All these 


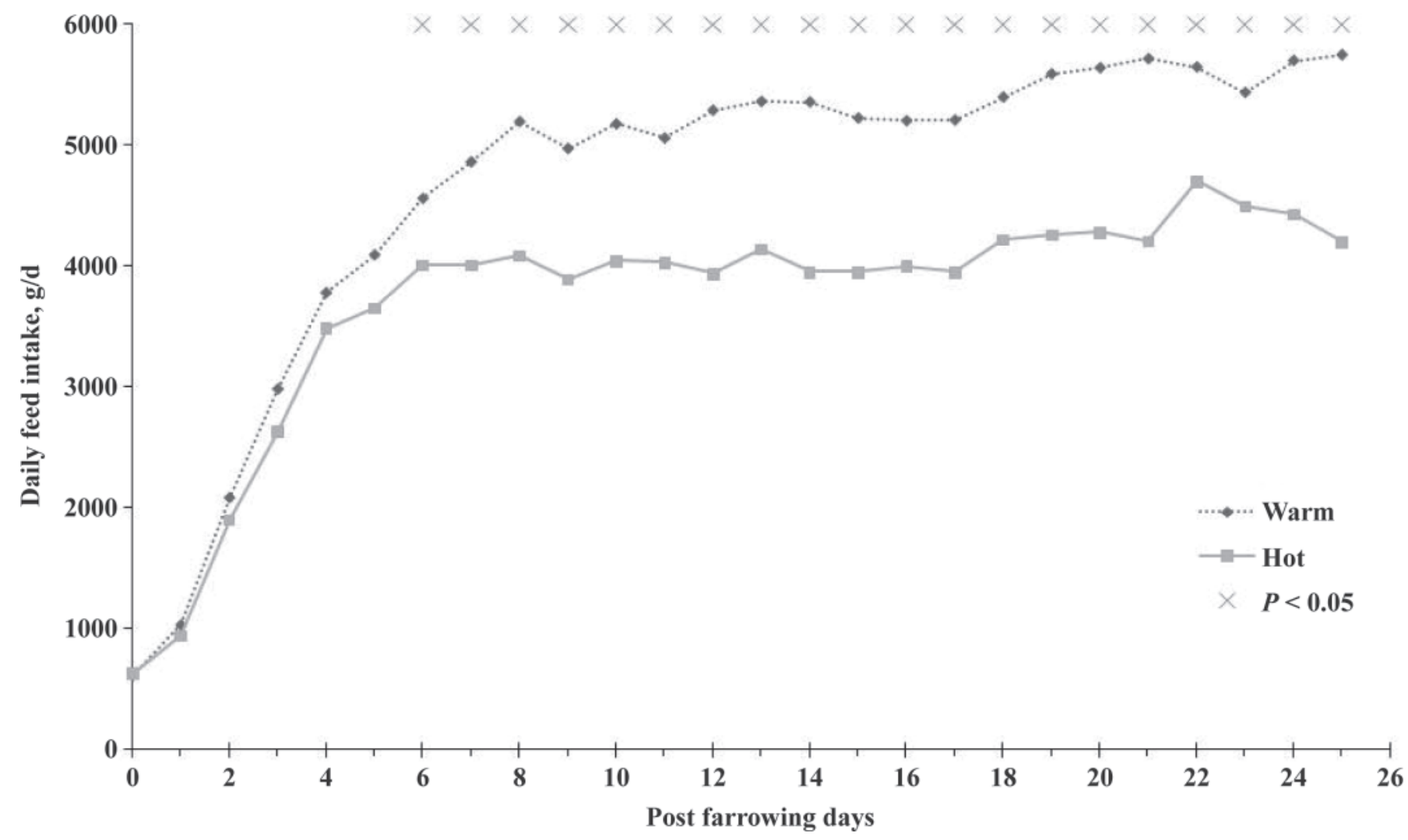

Figure 1. Effect of season on daily feed intake during the lactation period. Feed intake was not different between seasons from d 1 to 5 ( $P>$ $0.10)$, whereas it differed from d 6 to $25(\times ; P<0.05)$. A total of 33 and 53 sows were used for the warm and hot seasons, respectively.

processes produce to a short-term adaptation to hot climatic conditions via increased heat dissipation.

The negative effect of high temperatures on feed intake has been extensively described (Christon et al., 1999; Johnston et al., 1999; Quiniou and Noblet, 1999; Renaudeau et al., 2003; Gourdine et al., 2006). Quiniou and Noblet (1999) showed that the negative effect of temperature on ADFI is accentuated as the ambient temperature increases. In their study, they indicated that each degree increase in ambient temperature between 25 and $27^{\circ} \mathrm{C}$ at a $\mathrm{RH}$ fluctuating between 50 and $60 \%$ resulted in a reduction of feed intake equivalent to $214 \mathrm{~g} / \mathrm{d}$. In our study, over a similar temperature range between the 2 seasons and at approximately $94 \% \mathrm{RH}$, the corresponding value was more than twice as large $\left(492 \mathrm{~g} \cdot \mathrm{d}^{-1} \cdot{ }^{\circ} \mathrm{C}^{-1}\right)$. Renaudeau et al. (2003), evaluating the effects of dietary fiber content in the same tropical conditions as ours (i.e., a similar range of temperature and ambient humidity), observed a reduction of 584 $\mathrm{g} .{ }^{\circ} \mathrm{C}^{-1}$ in ADFI between both seasons. These results suggest that the reduction in feed intake of lactating sows kept in tropical climates is related to the combined effects of high temperatures and high humidity. This emphasizes that the high humidity accentuates the effect of high temperatures by limiting the capacity of evaporative heat loss from the lungs through increased respiratory rate (Renaudeau, 2005).

In the warm season, piglet growth rate over the first 3 wk of lactation $(194 \mathrm{~g} / \mathrm{d})$ was less than results reported in temperate conditions (Auldist and King, 1995:
265 g/d; Hulten et al., 2002: 290 g/d; Quiniou, 2005: $253 \mathrm{~g} / \mathrm{d}$ ). As observed for ADFI, this suggests that the sows in our study were heat stressed, and their milk production was depressed, even in the warm season. According to Quiniou and Noblet (1999) and Gourdine et al. (2006), milk yield is reduced at elevated temperatures. In the current study, the effect of season on milk production and on litter BW gain was significant, with decreased values observed during the hot season. Moreover, when milk production was expressed on a per piglet basis, the amount of milk available for each piglet decreased during the hot season. This indicates that the negative effect of heat stress on sow milk production was emphasized during the hot season. Independent of the season, piglet BW gain between $d 21$ and weaning was greater than piglet $\mathrm{BW}$ gain from wk 1 to wk 3 of lactation, likely due to creep feed consumption during this period. In the present study, piglets consumed similar amounts of creep feed during the warm and hot seasons (14 vs. $13 \mathrm{~g} \cdot \mathrm{d}^{-1} \cdot$ piglet $^{-1}$, respectively). In contrast to our findings, Renaudeau et al. (2001) reported a greater creep feed intake in piglets from sows maintained under heat stress conditions $(23$ vs. $38 \mathrm{~g} \cdot \mathrm{d}^{-1}$.piglet ${ }^{-1}$, respectively, for 20 and $29^{\circ} \mathrm{C} ; P<$ 0.01). According to these authors, piglets compensated for the decreased milk production by increasing their creep feed consumption, with a subsequent attenuated effect of heat stress on performance of the litter. The difference observed between our findings and the latter authors can be related to the observation that the 


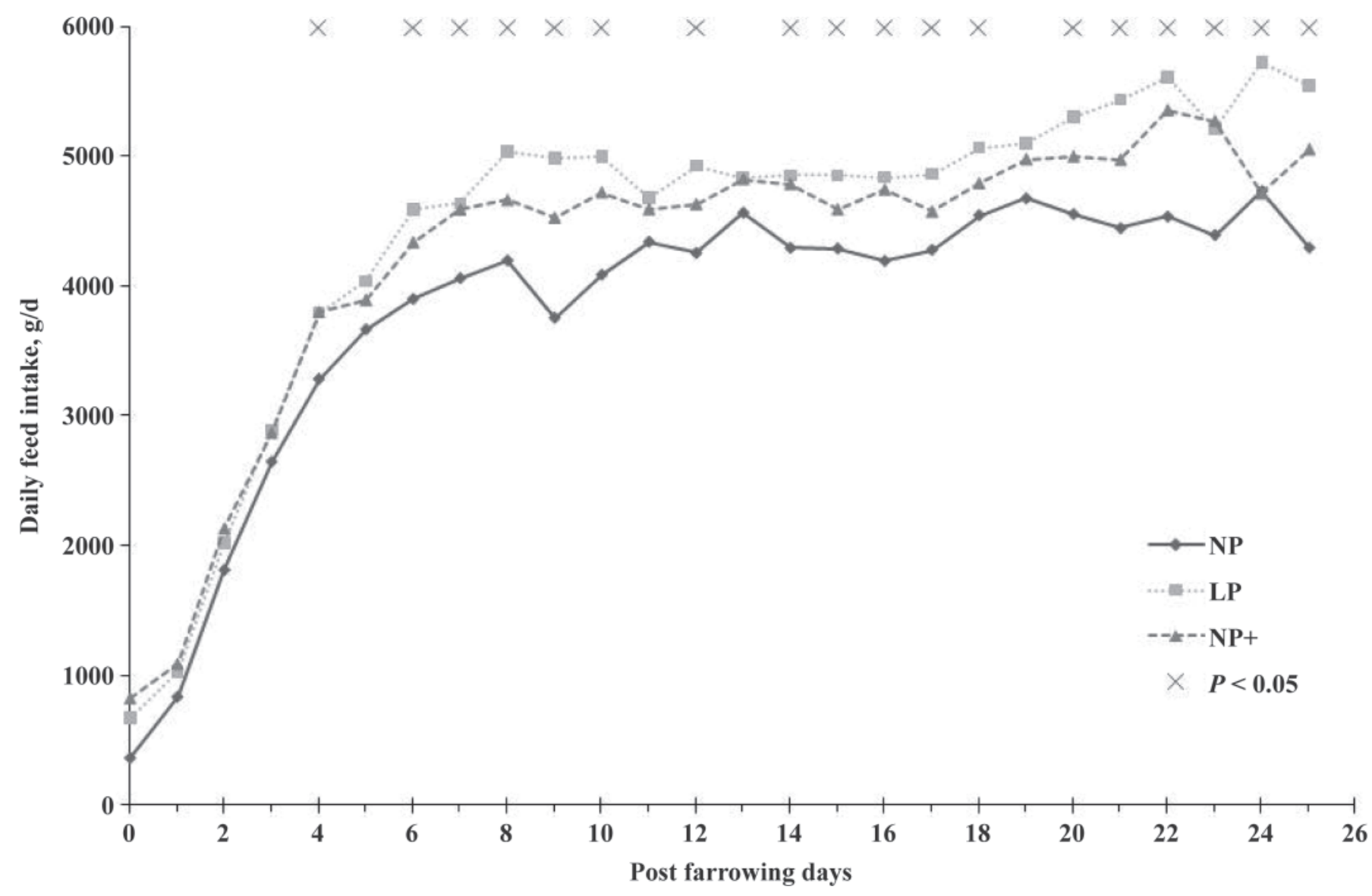

Figure 2. Effect of diet composition on daily feed intake during the lactation period. Feed intake was not different from d 1 to 3 and on d 5 , 11, 13, and $19(P>0.10)$, whereas it differed between diets on d 4 , from d 6 to $10, \mathrm{~d} 12, \mathrm{~d} 14$ to 18 , and from d 20 to $25(\times ; P<0.05)$. A total of 30,30 , and 26 sows were used for $\mathrm{NP}, \mathrm{LP}$, and $\mathrm{NP}+$, respectively. $\mathrm{NP}=$ normal protein diet; $\mathrm{LP}=$ low protein diet; $\mathrm{NP}+=\mathrm{NP}$ diet supplemented with an AA complement.

range of temperatures in our experiment was too small to affect creep feed intake $\left(2.4\right.$ vs. $9.0^{\circ} \mathrm{C}$, respectively, for our study and Renaudeau et al., 2001).

In agreement with Renaudeau and Noblet (2001), our results show an increased lipid content of milk in sows exposed to hot climatic conditions. Similar results were obtained at thermoneutrality when dietary energy supply was reduced and mobilization of body fat reserves was accentuated (Noblet and Etienne, 1986). Collectively, these studies suggest that elevated milk lipid concentrations that result when sows are exposed to high ambient temperatures are related to an increased mobilization of body fat reserves.

Sow BW, protein, lipid, energy, and backfat thickness losses were not affected by season. In contrast to our results, most studies investigating this area demonstrated that BW loss increases in heat-stressed sows in connection with a reduced ADFI (Christon et al., 1999; Johnston et al., 1999; Quiniou and Noblet, 1999; Renaudeau et al., 2003) and a smaller relative reduction of performance. A possible explanation for our findings is that the sows were more efficient to produce milk from feed energy than from energy mobilized from body stores in the hot season, resulting in no effects on chemical composition of BW loss (Noblet et al., 1990). Our study showed a significant effect of season on weaning to es- trus interval, whereby the sows showed a greater WEI in the hot season than in the warm season (i.e., 4.5 vs. 3.7 d). Shaw and Foxcroft (1985), Barb et al. (1993), Koketsu et al. (1997), and Van den Brand et al. (2000) also observed a negative effect of high temperature on the return to estrus of sows after weaning. According to these authors, the delay in the return to estrus after weaning was related to decreased secretion of $\mathrm{LH}$ in sows maintained in a hot environment.

\section{Effect of Dietary Protein Content on Sow and Litter Performance}

In the present study, LP sows tended to have increased ADFI $(+0.540 \mathrm{~kg})$ when compared with the NP diet sows. Our results show that the increase of ADFI with LP diet was quite similar in multiparous and in primiparous sows $(+11 \%$, respectively). Renaudeau and Noblet (2001) evaluating the effect of protein reduction (14.2 vs. $17.6 \%)$ also reported a numerical increase of ADFI at $29^{\circ} \mathrm{C}$ for sows fed LP diet $(+0.639 \mathrm{~kg})$. Lynch (1989) also observed an increased feed consumption $(+0.700 \mathrm{~kg} / \mathrm{d})$ in multiparous lactating sows fed a low $\mathrm{CP}$ diet (14 vs. $20 \%$ ) at $28^{\circ} \mathrm{C}$. In contrast, Quiniou and Noblet (1999) did not report any effect of diet on performance of lactating sows kept at $29^{\circ} \mathrm{C}$ when dietary 
Table 5. Effect of season and diet composition on performance of litters over a 28-d lactation (least squares means)

\begin{tabular}{|c|c|c|c|c|c|c|c|}
\hline \multirow[b]{2}{*}{ Variable } & \multicolumn{3}{|c|}{$\operatorname{Diet}^{1}$} & \multicolumn{2}{|c|}{ Season } & \multirow[b]{2}{*}{$\mathrm{RSD}^{2}$} & \multirow{2}{*}{$\begin{array}{l}\text { Statistical } \\
\text { analysis }^{3}\end{array}$} \\
\hline & NP & LP & $\mathrm{NP}+$ & Warm & Hot & & \\
\hline Parity & 3.3 & 3.2 & 3.3 & 3.3 & 3.2 & 1.2 & $\mathrm{P}^{* * *}$ \\
\hline Lactation length, d & 28.4 & 29.8 & 28.5 & 28.1 & 29.2 & 2.7 & \\
\hline \multicolumn{8}{|l|}{ Litter size } \\
\hline \multicolumn{8}{|l|}{ Piglet BW, kg } \\
\hline At d 1 & 1.4 & 1.4 & 1.4 & 1.4 & 1.4 & 0.2 & \\
\hline At d 14 & 4.2 & 4.2 & 4.2 & 4.3 & 4.2 & 0.7 & $\mathrm{G}^{*}$ \\
\hline At d 21 & 5.7 & 5.7 & 5.6 & 5.8 & 5.5 & 0.7 & \\
\hline At weaning & 7.5 & 7.4 & 7.1 & 7.5 & 7.1 & 0.8 & $\mathrm{~S} \dagger$ \\
\hline \multicolumn{8}{|l|}{ Litter BW gain, kg/d } \\
\hline Sow milk production, ${ }^{5} \mathrm{~kg} / \mathrm{d}$ & 7.6 & 7.3 & 7.5 & 8.1 & 6.8 & 1.4 & $\mathrm{~S}^{* *}, \mathrm{G}^{*}$ \\
\hline
\end{tabular}

protein content was reduced from 17 to $14 \%$. In that study, the authors attributed the lack of interaction between temperature and diet to the few number of observations, the reduced supplies of sulfur AA and Trp expressed as a percentage of Lys in the 14\% CP diet, or a combination of both. In addition, the reduction of dietary protein content with a supplementation of synthetic AA leads to increase the ratio between Trp and branched chain AA [long neutral AA (LNAA): Leu, Ile, Val, Phe, Tyr; i.e., 4.52 vs. $5.37 \%$ in NP and LP diet, respectively]. According to Tackman et al. (1990), Trp and LNAA share the same neutral carrier system to cross the blood-brain barrier, and they compete for uptake by the brain. Serotonin and its precursor, Trp, are known to be involved in the control of feed intake; an increased ratio of Trp:LNAA is reported to increase appetite linearly (Henry and Séve, 1993). Trottier and Easter (1995) reported that a reduction in the Trp:LNAA ratio through dietary addition of LNAA decreased feed intake of primiparous lactating sows. Thus, the increased ADFI in LP treatment may also be related to a reduced Trp:LNAA ratio.

Litter BW gain, milk production, and composition were not affected by dietary CP content. Similarly, Johnston et al. (1999) and Renaudeau et al. (2001) showed that lactating sows kept at $29^{\circ} \mathrm{C}$ exhibited no

Table 6. Effect of season and diet composition on milk composition ${ }^{1}$

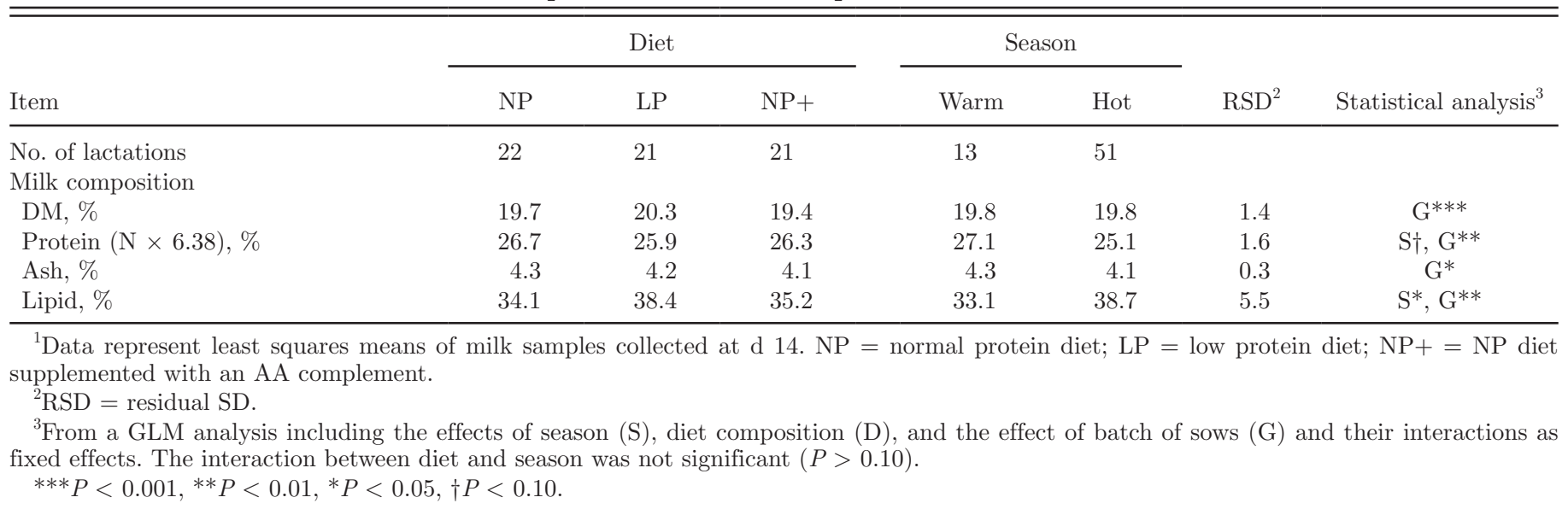


Table 7. Effect of season and diet composition on the weaning-to-estrus interval (least squares means)

\begin{tabular}{|c|c|c|c|c|c|c|c|}
\hline \multirow[b]{2}{*}{ Item } & \multicolumn{3}{|c|}{$\operatorname{Diet}^{1}$} & \multicolumn{2}{|c|}{ Season } & \multirow[b]{2}{*}{$\mathrm{RSD}^{2}$} & \multirow[b]{2}{*}{ Statistical analysis ${ }^{3}$} \\
\hline & NP & LP & $\mathrm{NP}+$ & Warm & Hot & & \\
\hline \multicolumn{8}{|l|}{ Weaning to estrus interval, $\mathrm{n}$} \\
\hline 1 to $3 \mathrm{~d}$ & 6 & 6 & 6 & 12 & 6 & & \\
\hline 3 to $5 \mathrm{~d}$ & 19 & 22 & 17 & 21 & 40 & & \\
\hline Weaning to estrus interval, d & \multicolumn{3}{|c|}{$\chi^{2}=0.74, P=0.94$} & \multicolumn{2}{|c|}{$\chi^{2}=9.50, P=0.009$} & & \\
\hline
\end{tabular}

change in litter BW gain when dietary CP level was decreased (from 16.7 to $13.3 \%$; and from 17.6 to $14.2 \%$, respectively).

Evaluating the effect of dietary CP content on the performance of lactating sows under heat stress, Renaudeau et al. (2001) observed that the LP sows showed a greater daily feed intake and lost less BW in comparison with NP sows. In the present study, the reduction of BW mobilization in sows fed LP diet was very small $(-1.6 \mathrm{~kg})$. The estimated chemical composition of BW loss was not affected by the diet composition. On average, each $100 \mathrm{~g}$ of BW loss contained $14 \mathrm{~g}$ of protein and $47 \mathrm{~g}$ of lipid. Evaluating diets comparable with ours, Renaudeau et al. (2001) reported similar values of body nutrient change (12 and 46\%, respectively, for protein and lipid content in BW loss) for multiparous sows over a 27-d lactation. In our study, the lack of a significant impact of diet on reproductive performance was attributed to the observation that dietary treatment did not affect mobilization of body reserves.

\section{Effect of Dietary AA Content on Sow and Litter Performance}

In the present study, sows fed NP+ diet showed, on average, $+10.6 \%$ greater ADFI when compared with sows fed the NP diet. Because of the small number of primiparous sows, we did not evaluate their performance independently. However, greater feed intake observed for the NP+ sows can be partly attributed to a greater effect on primiparous sows, which had greater feed intakes when fed an AA complement. In contrast to our results, Tokach et al. (1992) and Paiva et al. (2005), evaluating the effects of dietary Lys levels in lactating primiparous sows, via an addition of synthetic AA, did not observe a significant effect of the increase of AA content on ADFI.

Piglet and litter performance and sows milk production were not affected by the dietary AA complement. Similarly, Trottier and Easter (1995), Dourmad et al. (1998), and Paiva et al. (2005) also did not observe any effect of increasing dietary AA content on piglet and litter performance and on the milk yield of sows. Milk composition was not affected by dietary AA content. Similarly, Trottier and Easter (1995) also did not observe any effect of increasing dietary AA content on milk composition of sows.

The results of BW, protein, lipid losses, as well as changes in backfat thickness obtained in our study, were not affected by the dietary AA supplementation. Nevertheless, when compared between NP+ and NP, a numerical less BW mobilization was observed for the sows fed the $\mathrm{NP}+$ diet, but these results are related to the performance of the primiparous sows, which were more affected by AA supplementation. This result can be associated to the effect of the greater Lys intake observed in these primiparous sows (i.e., $+11 \mathrm{~g} / \mathrm{d}$ ), which can also be related to the numerical greater ADFI observed for the sows (i.e., +460 g). Stahly et al. (1992), Johnston et al. (1993), and Dourmad et al. (1998) also reported that the loss of BW was affected by Lys supply, whereas increasing Lys levels in the diets reduced BW loss.

In conclusion, the present study demonstrates that high ambient temperature had an important negative effect on feed intake and more generally on performance of lactating sows, and these negative impacts are exacerbated when the RH is high. Regardless of season, the use of diets with reduced TEF or supplemented with an AA complement in lactation may allow an increase in ADFI and partially attenuate the negative effects of tropical climate on performance of sows. The addition of AA supplementation in diets for primiparous sows may attenuate the effects of heat stress on the performance of these animals, but this assumption needs to be more thoroughly investigated with a greater number of sows.

\section{LITERATURE CITED}

AOAC. 1990. Official Methods of Analysis. 15th ed. Assoc. Off. Anal. Chem., Washington, DC.

Auldist, D. E., and R. H. King. 1995. Piglets' role in determining milk production in the sow. Pages 114-118 in Manipulating 
Pigs Prod. V. Hennessy and P. D. Cranwell, ed. Aust. Pig Sci. Assoc. Anim. Res. Inst., Werribee, Australia.

Barb, C. R., M. J. Estienne, R. R. Kraeling, D. N. Marple, G. B. Rampacek, C. H. Rahe, and J. L. Sartin. 1993. Endocrine changes in sows exposed to elevated ambient temperature during lactation. Domest. Anim. Endocrinol. 8:117-127.

Berbigier, P. 1988. Description des climats équatoriaux et tropicaux. Pages 11-18 in INRA Ed. Bioclimatologie des ruminants domestiques en zone tropicale. INRA Publ., Paris, France.

Black, J. L., M. L. Mullan, M. L. Lorschy, and L. R. Giles. 1993. Lactation in the sow during heat stress. Livest. Prod. Sci. 35:153-170.

Christon, R., G. Saminadin, H. Lionet, and B. Racon. 1999. Dietary fat and climate alter food intake, performance of lactating sows and their litters and fatty acid composition of milk. Anim. Sci. 69:353-365.

Dourmad, J. Y., M. Etienne, J. Noblet, and D. Causeur. 1997. Prédiction de la de la composition chimique des truies reproductrices à partir du poids vif et de l'épaisseur de lard dorsal. J. Rech. Porcine France 29:255-262.

Dourmad, J. Y., J. Noblet, and M. Etienne. 1998. Effect of protein and lysine supply on performance, nitrogen balance, and body composition changes of sows during lactation. J. Anim. Sci. 76:542-550.

Gourdine, J. L., J. P. Bidanel, J. Noblet, and D. Renaudeau. 2006. Effects of season and breed on performance of lactating sows in a tropical humid climate. J. Anim. Sci. 84:360-369.

Henry, Y., and B. Séve. 1993. Feed intake and dietary amino acid balance in growing pigs with special reference to lysine, tryptophan and threonine. Pig News Inf. 14:35-43.

Hulten, F., A. Valros, M. Rundgren, and S. Einarsson. 2002. Reproductive endocrinology and post-weaning in the multiparous sow. Part 2. Influence of nursing behaviour. Theriogenology 58:1519-1530.

Jeon, J. H., S. C. Yeon, Y. H. Choi, W. Min, S. Kim, P. J. Kim, and H. H. Chang. 2006. Effects of chilled drinking water on the performance of lactating sows and their litters during high ambient temperatures under farm conditions. Livest. Sci. 105:86-93.

Johnston, L. J., M. Ellis, G. W. Libal, V. B. Mayrose, and W. C. Weldon., and NRC. 1999. Effect of room temperature and dietary amino acid concentration on performance of lactating sows. J. Anim. Sci. 77:1638-1644.

Johnston, L. J., J. E. Pettigrew, and J. W. Rust. 1993. Response of maternal-line sows to dietary protein concentration during lactation. J. Anim. Sci. 71:2151-2156.

Koketsu, Y., G. D. Dial, J. E. Pettigrew, and V. L. King. 1997. Influence of feed intake during individual weeks of lactation on reproductive performance of sows on commercial farms. Livest. Prod. Sci. 49:217-225.

Le Bellego, L., J. Noblet, and J. van Milgen. 2002. Effect of high temperature and low protein diets on performance of growingfinishing pigs. J. Anim. Sci. 80:691-701.

Lorschy, M. L., L. R. Giles, C. R. Smith, J. M. Gooden, and J. L. Black. 1991. Food intake, heat production and milk yield of lactating sows exposed to high temperature. Page 81 in APSA Committee (ed.) Manipulating Pig Production. Australasian Pig Science Assoc., Animal Research Institute, Werribee, Australia.

Lynch, P. B. 1989. Voluntary food intake of sows and gilts. Pages 71-77 in Pig Housing and the Environment. A. T. Smith and T. L. J. Lawrence, ed. Br. Soc. Anim. Prod., Edinburgh, UK.

McGlone, J. J., W. F. Stansbury, and L. F. Tribble. 1988. Management of lactating sows during heat stress: Effects of water drip, snout coolers, floor type and a high energy-density diet. J. Anim. Sci. 66:885-891.

Noblet, J., J. Y. Dourmad, and M. Etienne. 1990. Energy utilization in pregnant and lactating sows: Modelling of energy requirements. J. Anim. Sci. 68:562-572.
Noblet, J., and M. Etienne. 1986. Effect of energy level in lactating sows on yield and composition of milk and nutrient balance of piglets. J. Anim. Sci. 66:1888-1896.

Noblet, J., and M. Etienne. 1989. Estimation of sow milk nutrient output. J. Anim. Sci. 67:3352-3359.

Noblet, J., H. Fortune, X. S. Shi, and S. Dubois. 1994. Prediction of net energy value of feeds for growing pigs. J. Anim. Sci. $72: 344-354$.

NRC. 1998. Nutrient Requirements of Swine. 10th ed. Natl. Acad. Press, Washington, DC.

Paiva, F. P., J. L. Donzele, R. F. M. Oliveira, M. L. T. Abreu, L. R. Apolonio, C. A. A. Torres, and A. M. S. Moita. 2005. Lisina em raçoes para femeas suinas primiparas em lactataçao. Braz. J. Anim. Sci. 34:1971-1979.

Quiniou, N. 2005. Influence de la quantité d'aliment alloué à la truie en fin de gestation sur le déroulement de la mise bas, la vitalité des porcelets et les performances de lactation. J. Rech. Porcine France 37:187-194.

Quiniou, N., and J. Noblet. 1999. Influence of high ambient temperatures on performance of multiparous lactating sows. J. Anim. Sci. 77:2124-2134.

Renaudeau, D. 2005. Effects of short-term exposure to high ambient temperature and relative humidity on thermoregulatory responses of European (Large White) and Caribbean (Creole) restrictively fed growing pigs. Anim. Res. 54:81-93.

Renaudeau, D., C. Anais, and J. Noblet. 2003. Effects of dietary fiber on performance of multiparous lactating sows in a tropical climate. J. Anim. Sci. 81:717-725.

Renaudeau, D., and J. Noblet. 2001. Effects of exposure to high ambient temperature and dietary protein level on sow milk production and performance of piglets. J. Anim. Sci. 79:1540-1548.

Renaudeau, D., N. Quiniou, and J. Noblet. 2001. Effects of exposure to high ambient temperature and dietary protein level on performance of multiparous lactating sows. J. Anim. Sci. 79:1240-1249.

Sauvant, D., J. M. Perez, and G. Tran. 2002. Tables de composition et de valeur nutritive des matières premières destinées aux animaux d'élevage. AFZ-INRA. pp. 1-301.

Shaw, H. J., and G. R. Foxcroft. 1985. Relationships between LH, FSH and prolactin secretion and reproductive activity in the weaned sow. J. Reprod. Fertil. 75:17-28.

Silva, B. A. N., R. F. M. Oliveira, J. L. Donzele, H. C. Fernandes, M. L. T. Abreu, J. Noblet, and C. G. V. Nunes. 2006. Effect of floor cooling on performance of lactating sows during summer. Livest. Sci. 105:176-184.

Stahly, T. S., G. L. Cromwell, and H. J. Monegue. 1992. Milk yield responses of sows nursing large litters to dietary amino acid levels. J. Anim. Sci. 70(Suppl. 1):238. (Abstr.)

Tackman, J. M., J. K. Tews, and A. E. Harper. 1990. Dietary disproportions of amino acids in the rats: Effects on food intake, plasma and brain amino acids and brain serotonin. J. Nutr. 120:521-533.

Tokach, M. D., J. E. Pettigrew, and G. G. Dial. 1992. Characterization of luteinizing hormone secretion in the primiparous sows: Relationship to blood metabolites and return-to-estrus. J. Anim. Sci. 70:2195-2201.

Trottier, N. L., and R. A. Easter. 1995. Dietary and plasma branched-chain amino acids in relation to tryptophan: Effect on voluntary feed intake and lactation metabolism in the primiparous sow. J. Anim. Sci. 73:1086-1092.

Van den Brand, H., S. J. Dieleman, N. M. Soede, and B. Kemp. 2000. Dietary energy source at two feeding levels during lactation of primiparous sows: I. Effects on glucose, insulin, and luteinizing hormone and on follicle development, weaning-toestrus interval, and ovulation rate. J. Anim. Sci. 78:369-404.

Van Soest, P. J., and R. H. Wine. 1967. Use of detergents in the analysis of fibrous feeds. IV. Determination of plant cell-wall constituents. J. AOAC 50:50-55. 
References

This article cites 33 articles, 17 of which you can access for free at: http://www.journalofanimalscience.org/content/87/12/4003\#BIBL 